\title{
Phosphate solubilizing bacteria: Assessment of their effect on growth promotion and phosphorous uptake of mung bean (Vigna radiata [L.] R. Wilczek)
}

\author{
Buddhi Charana Walpola ${ }^{1}$, and Min-Ho Yoon ${ }^{1 *}$
}

\begin{abstract}
The aim of this work was to isolate phosphate solubilizing bacteria (PSB) and assess their effect on the growth of mung bean (Vigna radiata [L.] R. Wilczek) plants. Of 31 isolated PSB strains, two efficient strains, identified as Pantoea agglomerans (PSB-1) and Burkholderia anthina (PSB-2), were employed in further studies. Maximum P solubilization $\left(720.75 \mu \mathrm{g} \mathrm{mL} \mathrm{L}^{-1}\right)$ was recorded from the cultures co-inoculated with P. agglomerans and B. anthina. A strong positive correlation was found between $\mathrm{pH}$ and soluble $\mathrm{P}$ concentration in the medium, as well as between titratable acidity and P solubilization. Both strains under greenhouse conditions remarkably enhanced shoot and root length, shoot and root dry matter, and P uptake of mung bean plants. Growth was found to be further improved by adding tricalcium phosphate (TCP) with PSB inoculation. Co-inoculation of both PSB strains and adding TCP exhibited the highest growth performances and P uptake of mung bean plants; this implies that their applicability as a promising alternative to minimize the P problem in agricultural soils.
\end{abstract}

Key words: Burkholderia anthina, co-inoculation, Pantoea agglomerans, phosphate solubilization, tricalcium phosphate, Vigna radiata.

\section{INTRODUCTION}

Despite the high total soil $\mathrm{P}$ content, plant $\mathrm{P}$ availability is often reported to be limited, particularly in tropical soils (Collavino et al., 2010). Most soil P is usually present as insoluble metal chelates (Vassilev et al., 2006); moreover, substantial amounts of applied chemical phosphate fertilizers are also rapidly converted into insoluble phosphate sources. This leads to regularly applying P fertilizers, which are not only costly, but also environmentally undesirable. In this context, microbial solubilization of soil insoluble phosphates into soluble forms is considered an important process in natural and agricultural ecosystems.

Several bacterial and fungal species with varied potentials to solubilize inorganic phosphates, also known as phosphate solubilizing microorganisms, have been found in the rhizosphere of plants. However, their number is not high enough to compete with other microbial species in the rhizosphere (Jain et al., 2012). Screening of potential phosphate solubilizing isolates, which can be used as bio-inoculants to increase plant growth and yield, is recognized as an area of interest because such microbial inoculants could substantially reduce the chemical fertilizer requirement. There are several previous reports

${ }^{1}$ Chungnam National University, College of Agriculture and Life Sciences, Daejeon, 305-764, Korea.

*Corresponding author (mhyoon@cnu.ac.kr).

Received: 3 January 2013.

Accepted: 22 July 2013.

doi:10.4067/S0718-58392013000300010 dealing with the application of phosphate solubilizing bacteria (PSB), either individually or combined, to assess their effects on the growth and biomass production of several crops (Fernández et al., 2007; Mittal et al., 2008; Vikram and Hamzehzarghani, 2008; Hariprasad and Niranjana, 2009; Jain et al., 2010). In the present study, we isolated and identified PSB strains and assessed their effect on the growth and nutrient uptake of mung bean plants cultivated under greenhouse conditions.

\section{MATERIALS AND METHODS}

\section{Isolation and identification of bacterial strains}

Soils employed to isolate bacterial strains were collected from Chungchugnam-do Province, Gongju-Gun area in South Korea. Moist field soil was mixed with a sterile $0.85 \% \mathrm{NaCl}$ solution and shaken for $30 \mathrm{~min}$. Serial dilutions were inoculated with NBRIP (National Botanical Research Institute Phosphorus) agar plates containing $10 \mathrm{~g}$ glucose, $5 \mathrm{~g} \mathrm{Ca}_{3}\left(\mathrm{PO}_{4}\right)_{2}, 5 \mathrm{~g} \mathrm{MgCl}_{2} \cdot 6 \mathrm{H}_{2} \mathrm{O}, 0.25 \mathrm{~g}$

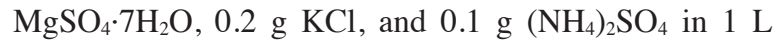
distilled water (Nautiyal, 1999). Medium $\mathrm{pH}$ was adjusted to 7 with $\mathrm{HCl}$. Plates were incubated for $5 \mathrm{~d}$ at $30{ }^{\circ} \mathrm{C}$. Colonies with clear halos were considered as phosphate solubilizing colonies (Vyas et al., 2007). A total of 31 bacterial isolates that exhibited clear zones on the agar plates were selected as phosphate solubilizing organisms. Based on the size of the clear zone, two bacterial isolates were selected as the efficient phosphate solubilizing organisms for further studies (PSB-1 and PSB-2).

Partial sequencing of $16 \mathrm{~S}$ rRNA for the bacterial strains 
was performed with the help of a DNA sequencing service (Solgent, Daejeon, South Korea) with universal primers, 27F (5'-AGAGTTTGATCCTGGCTCAG-3'), and 1492R (5'-GGTTACCTTGTTACGACTT-3'). Polymerase chain reaction (PCR) was performed with initial denaturation at $95{ }^{\circ} \mathrm{C}$ for 2 min followed by 30 cycles with denaturation for $30 \mathrm{~s}$ at $94{ }^{\circ} \mathrm{C}$, annealing for $30 \mathrm{~s}$ at $58^{\circ} \mathrm{C}$, and extension for $45 \mathrm{~s}$ at $72{ }^{\circ} \mathrm{C}$. The final extension was held for $5 \mathrm{~min}$ at $72{ }^{\circ} \mathrm{C}$. The online program BLAST (NCBI, 2012) was used in identifying the related sequences with known taxonomic information available at the databank of National Center for Biotechnology Information (NCBI, Bethesda, Maryland, USA). A phylogenetic tree was constructed with the CLUSTAL X program (Thompson et al., 1997), which involved sequence alignment by the neighbor-joining method (Saitou and Nei, 1987) and maximum parsimony with the MEGA4 program (Kumar et al., 2001). The grouping of sequences was based on confidence values obtained by bootstrap analysis of 1000 replicates. Gaps were edited in the BioEdit program (Hall, 1999) and evolutionary distances were calculated by Kimura's two-parameter model (Kimura, 1980). Reference sequences were retrieved from GenBank under the accession numbers indicated in the trees. The obtained sequences were deposited in the NCBI Genebank under accession numbers KF425001 (Pantoea agglomerans) and KF425002 (Burkhoderia anthina).

\section{Phosphate solubilization under in vitro conditions}

Inorganic phosphate solubilization was assayed in vitro as single inoculation and co-inoculation. Both $P$. agglomerans and $B$. anthina strains were grown in sterilized liquid NBRIP medium $(20 \mathrm{~mL})$ at $30{ }^{\circ} \mathrm{C}$ for 2 $\mathrm{d}$ with continuous shaking at $150 \mathrm{rpm}$. Aliquots $(1 \mathrm{~mL})$

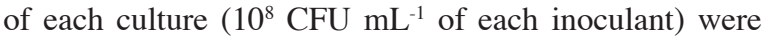
then transferred to a $500 \mathrm{~mL}$ flask ( $\mathrm{n}=3$ per strain) containing sterilized liquid NBRIP medium $(200 \mathrm{~mL})$ and incubated for $3 \mathrm{~d}$ with continuous shaking at $30{ }^{\circ} \mathrm{C}$.

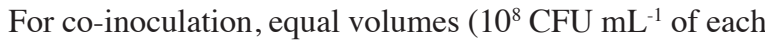
inoculant) of P.agglomerans and B. anthina cultures were transferred to a $500 \mathrm{~mL}$ flask. Sterilized uninoculated medium served as a control. A sample $(10 \mathrm{~mL})$ of each culture and control were taken and centrifuged at 8000 rpm for $10 \mathrm{~min}$. The clear supernatant was employed to determine the amount of $\mathrm{P}$ released into the medium. The culture medium $\mathrm{pH}$ was also recorded with the $\mathrm{pH}$ meter equipped with a glass electrode. Phosphorus availability was measured colorimetrically by the Murphy and Riley (1962) method. Bacteria growth was estimated by measuring absorbance at $660 \mathrm{~nm}$. Samples from cultures grown in NBRIP medium were diluted 1:1 (v/v) with $1 \mathrm{~N} \mathrm{HCl}$ to dissolve the residual insoluble phosphate and measured against a blank (Rodríguez et al., 2000). Titratable acidity produced by the strains during phosphate solubilization was determined by titration with 0.1 M NaOH (Takao, 1965).

\section{Inoculum preparation for pot experiment}

Single colonies of each strain were transferred to $500 \mathrm{~mL}$ flasks containing nutrient broth; colonies were then grown aerobically in flasks on a rotating shaker $(150 \mathrm{rpm})$ for $48 \mathrm{~h}$ at $30^{\circ} \mathrm{C}$. The bacterial suspension was then diluted in sterile distilled water to a final concentration of $10^{8}$ $\mathrm{CFU} \mathrm{mL} \mathrm{mL}^{-1}$ and resulting suspensions were used to treat mung bean seeds. Surface sterilized seeds were soaked in separate bacterial suspensions approximately $30 \mathrm{~min}$ prior to planting. For dual inoculation, an equal volume $\left(10^{8}\right.$ $\mathrm{CFU} \mathrm{mL} \mathrm{mL}^{-1}$ of each inoculant) of two cultures were mixed and then employed to treat mung bean seeds (the same as for single inoculation).

\section{Pot experiment}

The experiment was carried out in a greenhouse located at Chungnam National University, South Korea. The potting soil was classified as sandy loam and had the following characteristics: pH 6.55, $300 \mathrm{mg} \mathrm{NH}_{4}{ }^{+}-\mathrm{N} \mathrm{kg}^{-1}, 300 \mathrm{mg} \mathrm{NO}_{3}{ }^{-}$ $-\mathrm{N} \mathrm{kg}^{-1}, 255 \mathrm{mg} \mathrm{P}_{2} \mathrm{O}_{5} \mathrm{~kg}^{-1}$ (Olsen $\mathrm{P}$ ), and cation exchange capacity $(\mathrm{CEC})$ of $10 \mathrm{cmol}_{(+)} \mathrm{L}^{-1}$. Pots $(25 \mathrm{~cm}$ diameter, $35 \mathrm{~cm}$ height) were filled with this soil and basal $\mathrm{N}$ rates (50 mg kg-1 soil) and $\mathrm{K}$ (120 mg kg-1 soil) were applied as urea and potassium chlorite, respectively. Tricalcium phosphate (TCP) was supplied as soil P fertilizer at the rate of $160 \mathrm{mg} \mathrm{kg}^{-1}$ based on the nutrient requirements of mung bean plants. Pots were arranged in a randomized complete block design with three replicates per treatment. The experimental plan was based on eight treatments as follows: (1) Control; (2) Soil + TCP; (3) Soil + PSB-1; (4) Soil + PSB-1 + TCP; (5) Soil + PSB-2; (6) Soil + PSB-2 + TCP; (7) Soil + PSB-1 + PSB-2; and (8) Soil + PSB-1 + PSB-2 + TCP.

Mung bean (Vigna radiata (L.) R. Wilczek var. Paiyur 1) seeds were surface-sterilized by immersing them in $0.1 \%$ sodium hypochlorite solution for $10 \mathrm{~min}$ and then washing them three times with distilled water. A $15 \mathrm{~mm}$ depth of soil was removed from the earthen pots and six seeds were placed at equal distances. Previously prepared $1 \mathrm{~mL}$ samples of each inoculant were uniformly applied on seeds as single and coinoculation; seeds were then covered with a uniform $15 \mathrm{~mm}$ thick layer of soil. Control plants received $1 \mathrm{~mL}$ of diluted nutrient solution with no bacteria. Pots were watered daily to maintain soil field capacity during the study period. After $1 \mathrm{wk}$ of germination, plants were thinned out and three plants per plot were left. Effects of promoting bacterial growth treatments were assessed by measuring main shoot and root length, shoot and root weight, and $\mathrm{P}$ uptake of mung bean plants $8 \mathrm{wk}$ after planting. Root and shoot portions of plants were separated and air-dried before being kept in an oven at $70{ }^{\circ} \mathrm{C}$ to constant weight. Shoot and root dry weights were recorded separately and the mean weight of three plants was expressed as g plant ${ }^{-1}$. Plant samples were finely ground after drying and employed to determine 
plant $\mathrm{P}$ content by the Vanadate-Molybdate method described by Jackson (1973).

Analysis of $\mathrm{pH}$, available $\mathrm{P}$ content, and PSB population in soil

The samples of rhizosphere soil were aseptically separated by shaking and washing roots with sterile distilled water to test soil $\mathrm{pH}$, soil $\mathrm{P}$ content, and PSB population densities. Soil $\mathrm{pH}$ was measured in a 1:2.5 soil:water suspension with a pH meter (Model 440, Corning, Tewksbury Massachusetts, USA). Available soil Pwas extracted with sodium bicarbonate (pH 8.5) according to Olsen et al. (1954) and measured colorimetrically by the Murphy and Riley (1962) method.

The PSB population density was assessed by the pour plate method. The rhizosphere soil was collected by uprooting the plants. Soil adhering to the roots was serially diluted $\left(10^{2}\right.$ to $\left.10^{6}\right)$ with $0.85 \% \mathrm{NaCl}$ solution and aliquots from $0.1 \mathrm{~mL}$ of the sample from each of these dilutions were spread on a petri dish containing NBRIP medium. Plates were incubated $3 \mathrm{~d}$ in an incubator at 30 ${ }^{\circ} \mathrm{C}$. Colonies with clear halos were counted at the end of the incubation period.

\section{Statistical analysis}

Values were given as means \pm SD for triplicate samples. Data were subjected to ANOVA with the SAS package (SAS Institute, 1999). Duncan's Multiple Range Test (DMRT) was applied to test the significance of treatment means at $\mathrm{P} \leq 0.05$.

\section{RESULTS}

\section{Isolation and identification of bacterial strains}

A total of 31 bacterial isolates that exhibited clear zones on the agar plates were selected as phosphate solubilizing organisms. Two of these bacterial isolates were selected as efficient phosphate solubilizing organisms (PSB-1 and PSB-2). The two selected had a marked insoluble phosphate solubilizing ability as visualized by the clear zone development around the colonies after $3 \mathrm{~d}$ of incubation. According to $16 \mathrm{~S}$ rRNA sequence analysis, strains were identified as Pantoea agglomerans (PSB-1) and Burkholderia anthina (PSB-2). Comparison of the 16S rRNA sequence among available strains of Pantoea and Burkholderia species showed high homology (> 99\%) to P. agglomerans DSM3493 and B. anthina R4183. The neighbor-joining method was employed to construct the phylogenetic tree which illustrates the relationships of $16 \mathrm{~S}$ r RNA strain sequence and other Pantoea and Burkholderia species (Figure 1).

\section{Phosphate solubilization under in vitro conditions}

Changes in NBRIP medium $\mathrm{pH}$, microbial growth, titratable acidity, and soluble $\mathrm{P}$ content, released from inorganic $\mathrm{P}$, due to the addition of single and coinoculation of bacterial inoculants are shown in Table 1 . Significant $(\mathrm{P} \leq 0.05)$ increments in soluble $\mathrm{P}$ content, titratable acid production, and microbial growth were observed with PSB inoculation. A significant reduction in the $\mathrm{pH}$ of the PSB-inoculated medium was also observed as compared with the control where it remained constant ( $\mathrm{pH}$ 7). Co-inoculation of two PSB strains showed the highest phosphate solubilization when compared with single inoculation. A strong negative correlation between phosphate solubilization and $\mathrm{pH}$, as well as a strong positive correlation between phosphate solubilization and microbial growth can also be observed (Table 2). The higher amount of $\mathrm{P}$ observed in the co-inoculated medium

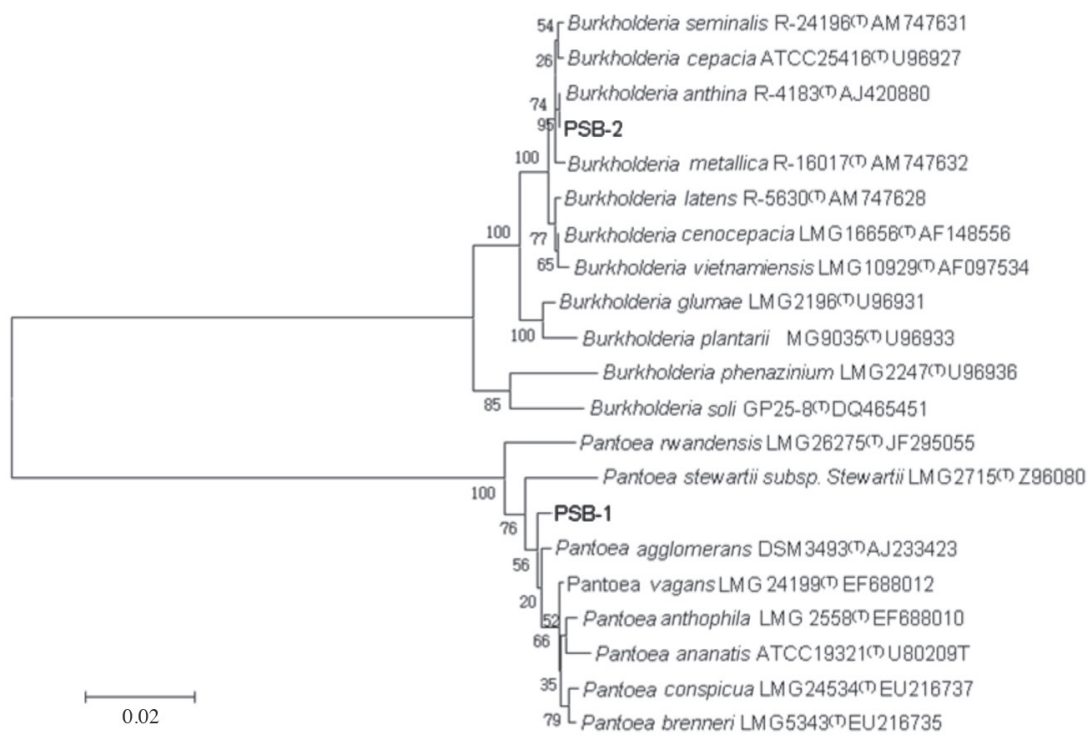

Figure 1. Phylogenetic tree based on 16S rDNA gene sequences showing the position of Pantoea agglomerans (PSB-1) and Burkholderia anthina (PSB-2) strains with regard to related species. The scale bar indicates 0.02 substitutions per nucleotide position. 
Table 1. Effects of single and co-inoculation of phosphate solubilizing bacteria (PSB) on phosphate solubilization.

\begin{tabular}{lcccc}
\hline Treatment & $\begin{array}{c}\text { Amounts of } \\
\text { soluble P }\end{array}$ & Dissolved & pH of medium & $\begin{array}{c}\text { Microbial growth (optical } \\
\text { density at 660 nm) }\end{array}$ \\
\hline & $\mu \mathrm{g} \mathrm{mL}^{-1}$ & $\%$ & & $\begin{array}{c}\text { Titratable } \\
\text { acidity }\end{array}$ \\
PSB-1 & $575.16 \pm 15.28 \mathrm{~b}$ & 57.56 & $3.21 \pm 0.12 \mathrm{~b}$ & $30.67 \pm 1.22 \mathrm{~b}$ \\
PSB-2 & $384.28 \pm 11.21 \mathrm{c}$ & 38.24 & $3.54 \pm 0.11 \mathrm{a}$ & $0.610 \pm 0.041 \mathrm{~b}$ \\
PSB-1 + PSB-2 & $720.75 \pm 14.37 \mathrm{c}$ & 72.07 & $3.04 \pm 0.09 \mathrm{c}$ & $0.407 \pm 0.034 \mathrm{c}$ \\
\hline
\end{tabular}

Values are given as means \pm SD for triplicate samples. Means followed by the same letter(s) in each column are not significantly different at $\mathrm{P} \leq 0.05$.

Table 2. Correlation coefficients of different parameters studied in single and co-inoculation of phosphate solubilizing bacteria (PSB).

\begin{tabular}{lcccc}
\hline & $\begin{array}{c}\text { Soluble } \\
\mathrm{P}\end{array}$ & $\begin{array}{c}\mathrm{pH} \text { of } \\
\text { medium }\end{array}$ & $\begin{array}{c}\text { Microbial } \\
\text { growth }\end{array}$ & $\begin{array}{c}\text { Titratable } \\
\text { acidity }\end{array}$ \\
\hline Soluble P & & $-0.94^{* *}$ & $0.92^{* *}$ & $0.88^{* *}$ \\
pH of medium & & & $-0.99^{* *}$ & $-0.95^{* *}$ \\
Microbial growth & & & & $0.98^{* *}$ \\
Titratable acidity & & & &
\end{tabular}

${ }^{* *}$ Highly significant.

can be attributed to higher microbial growth, which seems to be influenced by the synergistic action of the two PSB strains.

\section{Growth and $P$ uptake in mung bean plants}

Increased shoot length, root length, and shoot and root dry weight of mung bean plants were recorded from the seedlings raised with the PSB-inoculated seeds (Table 3 ). The best growth performances $(24.16 \mathrm{~cm}, 27.22 \mathrm{~cm}, 2.88$, and $2.93 \mathrm{~g} \mathrm{plant}^{-1}$ for shoot length, root length, shoot dry weight, and root dry weight, respectively) were recorded from the plants co-inoculated with $P$. agglomerans and $B$. anthina and amended with TCP. Although adding TCP resulted in better growth performances, no significant ( $P$ $\leq 0.05$ ) differences in shoot length, root length, and shootroot dry weight were observed among soil treatments with and without TCP (Table 3).

As shown in Table 4, $\mathrm{P}$ uptake of mung bean plants showed a trend similar to the growth parameters. An increase in shoot $\mathrm{P}$ uptake, root $\mathrm{P}$ uptake, and total $\mathrm{P}$ uptake was observed in plants inoculated with $P$. agglomerans or B. anthina or both. Moreover, adding TCP to the PSB-inoculated seeds significantly $(\mathrm{P} \leq 0.05)$ increased shoot and root $\mathrm{P}$ uptake. Co-inoculation of PSB strains with TCP further improved P uptake as compared with single inoculation with any of the PSB strains and TCP combination. Maximum P uptake (177.46 and $78.65 \mathrm{mg}$ plant $^{-1}$ for shoot and root, respectively) was recorded for co-inoculated plants with TCP. There was no significant difference $(\mathrm{P} \leq 0.05)$ between uninoculated seeds treated with and without TCP.

\section{Changes in $\mathbf{p H}$, available soil $\mathbf{P}$, and PSB population}

The effect of single and co-inoculation of PSB strains on soil $\mathrm{pH}$, available $\mathrm{P}$ content, and total PSB population are shown in Table 5. A more significant decrease $(\mathrm{P} \leq 0.05)$ in soil $\mathrm{pH}$ was recorded from PSB-inoculated soils than uninoculated soils. However, no significant $(\mathrm{P} \leq 0.05)$ difference in soil $\mathrm{pH}$ was observed among single and coinoculated soils. Furthermore, available P content in the rhizosphere soil inoculated either by single PSB or both strains were found to be significantly $(\mathrm{P} \leq 0.05)$ higher than for uninoculated soil. This was further improved by adding TCP. The highest available P content $(201.25 \mathrm{mg}$ $\mathrm{kg}^{-1}$ soil) recorded from co-inoculation of PSB strains with TCP was two times higher than for uninoculated soil. A

Table 4. Effect of Pantoea agglomerans (PSB-1) and Burkholderia anthina (PSB-2) on mung bean plant $P$ uptake.

\begin{tabular}{lccc}
\hline Treatment & $\begin{array}{c}\text { P content in } \\
\text { shoots }\end{array}$ & $\begin{array}{c}\text { P content } \\
\text { in roots }\end{array}$ & $\begin{array}{c}\text { Total P } \\
\text { uptake }\end{array}$ \\
\cline { 2 - 4 } & $\begin{array}{l}136.55 \pm 2.47 \mathrm{~b} \\
\text { Control }\end{array}$ & $47.86 \pm 0.57 \mathrm{~d}$ & $184.41 \pm 3.57 \mathrm{~b}$ \\
Soil + TCP & $136.71 \pm 1.57 \mathrm{~b}$ & $46.66 \pm 1.12 \mathrm{~d}$ & $183.36 \pm 4.11 \mathrm{~b}$ \\
Soil + PSB-1 & $141.12 \pm 2.87 \mathrm{~b}$ & $50.78 \pm 1.28 \mathrm{dc}$ & $191.91 \pm 3.89 \mathrm{~b}$ \\
Soil + PSB-1 + TCP & $173.71 \pm 2.11 \mathrm{a}$ & $73.18 \pm 1.07 \mathrm{~b}$ & $246.89 \pm 4.18 \mathrm{a}$ \\
Soil + PSB-2 & $140.91 \pm 1.58 \mathrm{~b}$ & $54.23 \pm 1.57 \mathrm{c}$ & $195.13 \pm 2.84 \mathrm{~b}$ \\
Soil + PSB-2 + TCP & $172.59 \pm 2.87 \mathrm{a}$ & $77.61 \pm 1.34 \mathrm{ba}$ & $250.19 \pm 3.57 \mathrm{a}$ \\
Soil + PSB-1 + PSB-2 & $140.07 \pm 3.47 \mathrm{~b}$ & $54.02 \pm 1.27 \mathrm{c}$ & $194.09 \pm 4.58 \mathrm{~b}$ \\
Soil + PSB-1 + PSB-2+TCP & $177.46 \pm 2.74 \mathrm{a}$ & $78.65 \pm 1.12 \mathrm{a}$ & $256.11 \pm 5.24 \mathrm{a}$ \\
\hline
\end{tabular}

Values are given as means \pm SD for triplicate samples. Means followed by the same letter(s) in each column are not significantly different at $\mathrm{P} \leq 0.05$.

PSB: phosphate solubilizing bacteria; TCP: tricalcium phosphate.

Table 3. Effect of Pantoea agglomerans (PSB-1) and Burkholderia anthina (PSB-2) on mung bean plant growth.

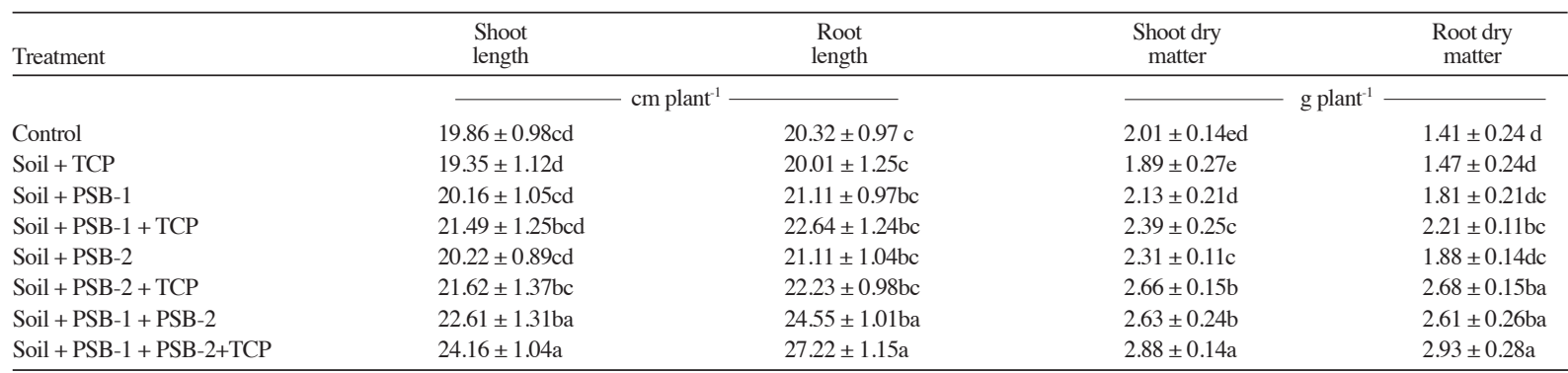

Values are given as means \pm SD for triplicate samples. Means followed by the same letter(s) in each column are not significantly different at $\mathrm{P} \leq 0.05$.

PSB: phosphate solubilizing bacteria; TCP: tricalcium phosphate. 
Table 5. Effect of Pantoea agglomerans (PSB-1) and Burkholderia anthina (PSB-2) on soil $\mathbf{p H}$, available $\mathbf{P}$ content, and population of phosphate solubilizing bacteria (PSB) in rhizosphere soil of mung bean plants.

\begin{tabular}{lccl}
\hline Treatment & \multicolumn{1}{c}{$\begin{array}{c}\text { Soil } \\
\mathrm{pH}\end{array}$} & $\begin{array}{c}\text { Soil } \\
\text { available P }\end{array}$ & $\begin{array}{c}\mathrm{nr} \text { of } \\
\text { PSB }\end{array}$ \\
\hline & & \multicolumn{1}{c}{$\mathrm{mg} \mathrm{kg}^{-1}$} & $\mathrm{CFU} \mathrm{g}^{-1}$ soil \\
Control & $6.52 \pm 0.32 \mathrm{a}$ & $106.91 \pm 1.35 \mathrm{e}$ & $1.17 \times 10^{2} \mathrm{~d}$ \\
Soil + TCP & $6.53 \pm 0.21 \mathrm{a}$ & $104.39 \pm 1.22 \mathrm{e}$ & $1.26 \times 10^{2} \mathrm{~d}$ \\
Soil + PSB-1 & $6.31 \pm 0.35 \mathrm{~b}$ & $169.81 \pm 2.34 \mathrm{cbd}$ & $4.61 \times 10^{4} \mathrm{~d}$ \\
Soil + PSB-1 + TCP & $6.31 \pm 0.12 \mathrm{~b}$ & $177.35 \pm 3.01 \mathrm{cb}$ & $5.41 \times 10^{5} \mathrm{c}$ \\
Soil + PSB-2 & $6.21 \pm 0.11 \mathrm{~b}$ & $159.75 \pm 1.57 \mathrm{~d}$ & $5.31 \times 10^{4} \mathrm{~d}$ \\
Soil + PSB-2 + TCP & $6.23 \pm 0.24 \mathrm{~b}$ & $164.78 \pm 2.24 \mathrm{~cd}$ & $5.68 \times 10^{5} \mathrm{c}$ \\
Soil + PSB-1 + PSB-2 & $6.28 \pm 0.31 \mathrm{~b}$ & $182.39 \pm 3.24 \mathrm{~b}$ & $6.91 \times 10^{6} \mathrm{~b}$ \\
Soil + PSB-1 + PSB-2+TCP & $6.28 \pm 0.28 \mathrm{~b}$ & $201.25 \pm 2.27 \mathrm{a}$ & $8.36 \times 10^{6} \mathrm{a}$
\end{tabular}

Values are given as means \pm SD for triplicate samples. Means followed by the same letter(s) in each column are not significantly different at $\mathrm{P} \leq 0.05$. PSB: phosphate solubilizing bacteria; TCP: tricalcium phosphate.

remarkable increase in the PSB population was observed in PSB-inoculated rhizosphere soil when compared with uninoculated soil. The highest PSB population $\left(8.36 \times 10^{6}\right.$ CFU g ${ }^{-1}$ soil) recorded from co-inoculation of PSB strains with TCP was approximately three times higher than for uninoculated soil.

\section{DISCUSSION}

Phosphate solubilization potential has been attributed to the strains' ability to reduce $\mathrm{pH}$ of the surroundings, either by releasing organic acids or protons (Hariprasad and Niranjana, 2009). Organic acids, such as gluconic acid, oxalic acid, and citric acid, secreted by PSB can directly solubilize mineral phosphate as a result of anion exchange or indirectly chelate both $\mathrm{Fe}$ and $\mathrm{Al}$ ions associated with phosphate. This leads to increased $\mathrm{P}$ availability, which ultimately increases plant $\mathrm{P}$ uptake. Studies on agar plates revealed that phosphate solubilizing microorganisms formed clear zones by solubilizing suspended TCP due to the release of organic acids into the surrounding medium (Gaur, 1990). In the present study, 31 PSB strains were isolated and two of these efficient PSB strains (P. agglomerans PSB-1 and B. anthina PSB-2) were selected for further studies; they had a marked insoluble phosphate solubilizing ability as visualized by the clear zone developed around the colonies. Previous reports also described some Burkholderia and Pantoea strains as being efficient phosphate solubilizers (Peix et al., 2001; Caballero-Mellado et al., 2007; Torres et al., 2008; Viruel et al., 2011; Khalimi et al., 2012; Silini-Cherif et al., 2012).

Titratable acidity is the total $\mathrm{H}^{+}$concentration which can be produced by different compounds (Whitelaw et al., 1999). Organic acid production due to PSB inoculation should be predictable from titratable acidity in the culture medium. From the results of the present study, it can be reaffirmed that $P$. agglomerans and $B$. anthina were involved in organic acid production. The negative correlation between $\mathrm{pH}$ and soluble $\mathrm{P}$ content of the medium, as well as the positive correlation between soluble $\mathrm{P}$ content and titratable acid production, suggested that acidification of the medium can facilitate phosphate solubilization. Co-inoculation showed a higher phosphate solubilizing ability than single inoculation; this suggests that both strains acted synergistically in phosphate solubilization. Yu et al. (2011) also reported similar findings after inoculating Pseudomonas chlororaphis and Bacillus megaterium.

Increased growth and $\mathrm{P}$ uptake of several crop plants due to PSB inoculation have been reported in a number of studies conducted under both growth chamber and greenhouse conditions (Dey et al., 2004; Fernández et al., 2007; Vikram and Hamzehzarghani, 2008; Hariprasad and Niranjana, 2009; Yu et al., 2011). The increase in shoot length, root length, shoot dry weight, and root dry weight of mung bean plants inoculated with PSB strains could be attributed to a greater absorption of nutrients, especially P. Compared with single inoculation, co-inoculation showed higher growth performances and P uptake; this suggests that both strains acted synergistically with each other to promote mung bean plant growth. However, phosphate solubilization is not the only way of promoting plant growth by PSB because they help plant growth by stimulating the efficiency of plant hormone production, such as auxins, cytokinins, gibberellins, and also some volatile compounds (Podile and Kishore, 2006). Enhanced plant growth after inoculation of PSB strains can be attributed to the ability of the strains to make $\mathrm{P}$ available and to simultaneously produce plant growth-promoting substances (Khalid et al., 2004; Linu et al., 2009; Ali et al., 2010).

Both strains used in this study exhibited the capacity to produce indoleacetic acid (data not shown); therefore, it might have contributed to enhanced shoot and root length through cell elongation and multiplication. A similar increase in growth and $\mathrm{P}$ uptake of mung bean plants due to inoculation of PSB strains was observed by Singh and Kapoor (1999), Vikram and Hamzehzarghani (2008), Ghanem and Abbas (2009), and Jha et al . (2011). Ghanem and Abbas (2009) observed an increase in plant height, number of branches, number of pods, grain weight, and eventually higher seed and straw yields in mung bean plants after inoculation of B. megaterium in salt-affected soils. Increased growth and $\mathrm{P}$ uptake have been reported for Azotobacter chroococcum in wheat (Kumar et al., 2001), Pseudomonas fluorescens in peanut (Dey et al., 2004), Pseudomonas species in wheat (Babana and Antoun, 2006), Pseudomonas species and Bacillus cereus in walnut (Yu et al., 2011), and Paenibacillus polymyxa and B. megaterium in tomato (EI-Yazeid and AbouAly, 2011). According to Fernández et al. (2007), shoot length of soybean plants increased after inoculation of Burkholderia sp. PER2F by $40 \%$ and $60 \%$ when compared with uninoculated soil/seed and uninoculated soil/seed treated with soluble $\mathrm{P}$, respectively. However, an increase in height and biomass, but not $\mathrm{P}$ content, of canola plants was observed by de Freitas et al. (1997) after inoculation 
of Bacillus and Xanthomonas, which are two PSB strains.

Results of the present study as to maximum plant growth and $\mathrm{P}$ uptake recorded with co-inoculation of two PSB strains with TCP are in line with the findings of Qureshi et al. (2011), who also observed similar results when co-inoculating phosphate solubilizing and noduleforming bacteria Rhizobium phaseoli and B. megaterium in mung bean plants. As for their observations, single rhizobium inoculation resulted in pod and straw yield of 24.0 and $30.20 \mathrm{~g} \mathrm{pot}^{-1}$, respectively, whereas the respective figures were 24.3 and $32.07 \mathrm{~g} \mathrm{pot}^{-1}$ for co-inoculation. Coinoculation also produced higher root mass $(231.3 \mathrm{~g})$, root length $(50.54 \mathrm{~cm})$, nodule number $(78)$, and nodular mass $(0.216 \mathrm{~g})$ as compared with the control.

Adding an insoluble phosphate source significantly increased total PSB populations in the soil, which implies that adding TCP was obviously beneficial for these isolates to proliferate and survive. Hence, more available $\mathrm{P}$ would be released into the soil and utilized by mung bean plants. A similar increase in the PSB population and available P content was observed by Yu et al. (2011). They also observed a positive correlation between available soil P content and PSB populations. A positive and significant correlation between phosphate solubilizing microorganisms and soil organic matter content was previously reported by Venkateswarlu et al. (1984). Other researchers (Vyas and Gulati, 2009) also reported decreased soil $\mathrm{pH}$ in PSB-inoculated soil and indicated organic acid production of both strains. Soil $\mathrm{pH}$ reduction was found to be much lower than in the culture medium (Table 1), which could be due to the buffering nature of the soil used in the experiment (Gyaneshwar et al., 1998).

\section{CONCLUSIONS}

This study has provided ample evidence to prove the strains' capacity to enhance plant growth. Co-inoculation of two PSB strains acted synergistically with each other and this was responsible for the increase in several growth parameters as compared with single inoculation. Nonetheless, further studies are needed under field conditions to confirm the present findings and their eventual commercial applications.

\section{LITERATURE CITED}

Ali, B., A.N. Sabri, and S. Hasnain. 2010. Rhizobacterial potential to alter auxin content and growth of Vigna radiata (L.) World Journal of Microbiology and Biotechnology 26:1379-1384.

Babana, A.H., and H. Antoun. 2006. Biological system for improving the availability of Tilemsi phosphate rock for wheat (Triticum aestivum L.) cultivated in Mali. Nutrient Cycling in Agroecosystems 76:285-295.

Caballero-Mellado, J., J. Onofre-Lemus, P. Estrada-de Los Santos, and L. Martínez-Aguilar. 2007. The tomato rhizosphere, an environment rich in nitrogen-fixing Burkholderia species with capabilities of interest for agriculture and bioremediation. Applied and Environmental Microbiology 73:5308-5319.
Collavino, M.M., P.A. Sansberro, L.A. Mroginski, and O.M. Aguilar. 2010. Comparison of in vitro solubilization activity of diverse phosphate-solubilizing bacteria native to acid soil and their ability to promote Phaseolus vulgaris growth. Biology and Fertility of Soils 46:727-738.

de Freitas, J.R., M.R. Banerjee, and J.J. Germida. 1997. Phosphatesolubilizing rhizobacteria enhance the growth and yield but not phosphorus uptake of canola (Brassica napus L.) Biology and Fertility of Soils 24:358-364.

Dey, R., K.K. Pal, D.M. Bhatt, and S.M. Chauhan. 2004. Growth promotion and yield enhancement of peanut (Arachis hypogaea L.) by application of plant growth-promoting rhizobacteria. Microbiological Research 159:371-394.

EI-Yazeid, A.A., and H.E. Abou-Aly. 2011. Enhancing growth, productivity and quality of tomato plants using phosphate solubilizing microorganisms. Australian Journal of Basic and Applied Sciences 7:371-379.

Fernández, L.A., P. Zalba, M.A. Gómez, and M.A. Sagardoy. 2007. Phosphate-solubilization activity of bacterial strains in soil and their effect on soybean growth under greenhouse conditions. Biology and Fertility of Soils 43:805-809.

Gaur, A.C. 1990. Phosphate solubilizing microorganisms as biofertilizers. Omega Scientific Publishers, New Delhi, India.

Ghanem, K.H.M., and E.E. Abbas. 2009. Improvement of mung bean growth and productivity in salinity-affected soil after seed inoculation with phosphate-dissolving bacteria. African Crop Science Conference Proceedings 9:385-389.

Gyaneshwar, P., G. Naresh Kumar, and L.J. Parekh. 1998. Effect of buffering on the phosphate-solubilizing ability of microorganisms. World Journal of Microbiology and Biotechnology 14:669-673.

Hall, T.A. 1999. BioEdit: a user-friendly biological sequence alignment editor and analysis program for Windows 95/98/NT. Nucleic Acids Symposium Series 41:95-98.

Hariprasad, P., and S.R. Niranjana. 2009. Isolation and characterization of phosphate solubilizing rhizobacteria to improve plant health of tomato. Plant and Soil 316:13-24.

Jackson, M.L. 1973. Soil chemical analysis. Prentice-Hall, New Delhi, India.

Jain, R., J. Saxena, and V. Sharma. 2010. The evaluation of free and encapsulated Aspergillus awamori for phosphate solubilization in fermentation and soil-plant system. Applied Soil Ecology 46:9094.

Jain, R., J. Saxena, and V. Sharma. 2012. Effect of phosphatesolubilizing fungi Aspergillus awamori S29 on mungbean (Vigna radiata cv. RMG 492) growth. Folia Microbiologica 57:533-541.

Jha, A., D. Sharma, and J. Saxena. 2011. Effect of single and dual phosphate solubilizing bacterial strain inoculations on overall growth of mung bean plants. Archives of Agronomy and Soil Science 58:967-981.

Khalid, A., M. Arshad, and Z.A. Zahir. 2004. Screening plant growth promoting rhizobacteria for improving growth and yield of wheat. Journal of Applied Microbiology 96:473-480.

Khalimi, K., D.N. Suprapta, and Y. Nitta. 2012. Effect of Pantoea agglomerans on growth promotion and yield of rice. Agricultural Science Research Journals 2:240-249.

Kimura, M. 1980. A simple method for estimating evolutionary rates of base substitutions through comparative studies of nucleotide sequences. Journal of Molecular Evolution 16:111-120.

Kumar, V., R.K. Behl, and N. Narula. 2001. Establishment of phosphate-solubilizing strains of Azotobacter chroococcum in the rhizosphere and their effect on wheat cultivars under green house conditions. Microbiological Research 156:87-93.

Kumar, S., K. Tamura, I.B. Jakobsen, and M. Nei. 2001. MEGA2: molecular evolutionary genetics analysis software. Bioinformatics 17:1244-1245.

Linu, M.S., J. Stephen, and M.S. Jisha. 2009. Phosphate solubilizing Gluconacetobacter sp., Burkholderia sp. and their potential interaction with cowpea (Vigna unguiculata (L.) Walp.) International Journal of Agricultural Research 4:79-87. 
Mittal, V., O. Singh, H. Nayyar, J. Kaur, and R. Tewari. 2008. Stimulatory effect of phosphate-solubilizing fungal strains (Aspergillus awamori and Penicillium citrinum) on the yield of chickpea (Cicer arietinum L. cv. GPF2). Soil Biology and Biochemistry 40:718-727.

Murphy, J., and J.P. Riley. 1962. A modified single solution method for the determination of phosphate in natural waters. Analytica Chimica Acta 27:31-36.

Nautiyal, C.S. 1999. An efficient microbiological growth medium for screening phosphate solubilizing microorganisms. FEMS Microbiology Letters 170:265-270.

NCBI. 2012. BLAST: Basic Local Alignment Search Tool. National Center for Biotechnology Information (NCBI), Bethesda, Maryland, USA. Available at http://www.ncbi.nlm.nih.gov/ BLAST (accessed on 28 November 2012).

Olsen, S.R., C.V. Cole, F.S. Watanabe, and L.A. Dean. 1954. Estimation of available phosphorus in soils by extraction with sodium bicarbonate. USDA Circular 939. 19 p. United States Department of Agriculture (USDA), Washington, DC., USA.

Peix, A., P.F. Mateos, C. Rodriguez-Barrueco, E. Martinez-Molina, and E. Velazquez. 2001. Growth promotion of common bean (Phaseolus vulgaris L.) by a strain of Burkholderia cepacia under growth chamber conditions. Soil Biology and Biochemistry 33:1927-1935.

Podile, A.R., and G.K. Kishore. 2006. Plant growth promoting rhizobacteria (PGPR). p. 195-230. In Gnanamanickam, S.S (ed.) Plant-associated bacteria. Springer, Dordrecht, The Netherlands.

Qureshi, M.A., M.A. Shakir, A. Iqbal, N. Akhtar, and A. Khan. 2011. Co-inoculation of phosphate solubilizing bacteria and rhizobia for improving growth and yield of mungbean (Vigna radiata $\mathrm{L}$.) Journal of Animal and Plant Sciences 21:491-497.

Rodríguez, H., T. Gonzalez, and G. Selman. 2000. Expression of a mineral phosphate solubilizing gene from Erwinia herbicola in two rhizobacterial strains. Journal of Biotechnology 84:155-161.

Saitou, N., and M. Nei. 1987. The neighbor-joining method: a new method for reconstructing phylogenetic trees. Molecular Biology and Evolution 4:406-425.

SAS Institute. 1999. SAS/STAT User's guide version 8. SAS Institute, Cary, North Carolina, USA

Silini-Cherif, H., A. Silini, M. Ghoul, and S. Yadav. 2012. Isolation and characterization of plant growth promoting traits of a rhizobacteria: Pantoea agglomerans Ima2. Pakistan Journal of Biological Sciences 15:267-276.
Singh, S., and K.K. Kapoor. 1999. Inoculation with phosphatesolubilizing microorganisms and a vesicular-arbuscular mycorrhizal fungus improves dry matter yield and nutrient uptake by wheat grown in a sandy soil. Biology and Fertility of Soils 28:139-144

Takao, S. 1965. Organic acid production by basidiomycetes. I. Screening of acid-producing strains. Applied Microbiology 13:732-737.

Thompson, J.D., T.J. Gibson, F. Plewniak, F. Jeanmougin, and D.G. Higgins. 1997. The CLUSTAL_X windows interface: flexible strategies for multiple sequence alignment aided by quality analysis tools. Nucleic Acids Research 25:4876-4882.

Torres, A.R., W.L. Araújo, L. Cursino, M. Hungria, F. Plotegher, F.L. Mostasso, and J.L. Azevedo. 2008. Diversity of endophytic enterobacteria associated with different host plants. Journal of Microbiology 46:373-379.

Vassilev, N., M. Vassileva, and I. Nikolaeva. 2006. Simultaneous P-solubilizing and biocontrol activity of microorganisms: potentials and future trends. Applied Microbiology and Biotechnology 71:137-144.

Venkateswarlu, B., A.V. Rao, and O. Raina. 1984. Evaluation of phosphorus solubilisation by microorganisms isolated from Aridisols. Journal of the Indian Society of Soil Science 32:273277.

Vikram, A., and H. Hamzehzarghani. 2008. Effect of phosphate solubilizing bacteria on nodulation and growth parameters of greengram (Vigna radiata L. Wilczek). Research Journal of Microbiology 3:62-72.

Viruel, E., M.E. Lucca, and F. Siñeriz. 2011. Plant growth promotion traits of phosphobacteria isolated from Puna, Argentina. Archives of Microbiology 193:489-496.

Vyas, P., and A. Gulati. 2009. Organic acid production in vitro and plant growth promotion in maize under controlled environment by phosphate-solubilizing fluorescent Pseudomonas. BMC Microbiology 9:174-189.

Vyas, P., P. Rahi, A. Chauhan, and A. Gulati. 2007. Phosphate solubilization potential and stress tolerance of Eupenicillium parvum from tea soil. Mycological Research 111:931-938.

Whitelaw, M.A., T.J. Harden, and K.R. Helyar. 1999. Phosphate solubilisation in solution culture by the soil fungus Penicillium radicum. Soil Biology and Biochemistry 31:655-665.

Yu, X., X. Liu, T.H. Zhu, G.H. Liu, and C. Mao. 2011. Isolation and characterization of phosphate-solubilizing bacteria from walnut and their effect on growth and phosphorus mobilization. Biology and Fertility of Soils 47:437-446. 